\title{
Talaqqī-Musyāfahah in Technology Based Learning Al-Qur'an Reading
}

\author{
$1^{\text {st }}$ Lilik Ummi Kaltsum ${ }^{1}$ \\ \{lilik.ummi@uinjkt.ac.id ${ }^{1}$ \} \\ UIN Syarif Hidayatullah Jakarta ${ }^{1}$
}

\begin{abstract}
Talaqqī-Musyāfahah is a key requirement in learning the Quran. TalaqqīMusyāfahah means the teacher and students must be through face-to-face meetings so that the teacher could clearly know the mouth of the students when reciting verses of the Quran. The culture of Talaqqī-Musyāfahah has existed since the time of the Prophet (PBUH). This culture has continued for generations until the time of the ulema (Muslim scholars) of the Qur'an. the transmission of the Quran is carried out under strict supervision so that the teacher is very responsible for the correctness of the pronunciation of students when reciting the Quran. However, this culture has begun to erode following the developments of science and technology. Consequently, internet access makes ones easily in learning to recite the Quran. This has in turn resulted in a decrease in the willingness of those willing to meet the teacher. finally, someone prefers to build a self-dicrected learning in dealing with the Qur'an without the TalaqqiMusyāfahah. This article will explore several internet programs related to learning the Qur'an and its tajwid rules. In addition, it will also evaluate the culture of the community in learning the Qur'an through the internet without Talaqqī-Musyāfahah, incluidng its impacts. The main purpose of this article is to prove that technological offerings related to learning the Quran could not deny the importance of Talaqqī-Musyāfahah between the teacher and students. This research is important because it will help open up the public insight. That the internet is only a tool to facilitate any learning process. However, the Quran recitation must be shown to the teacher through face-to-face meetings to be corrected.
\end{abstract}

Keywords: Talaqqī-Musyāfahah, Transmission, Science and Technology

\section{Introduction}

Learning is a two-way communication process. Teaching is done by teachers as educators and people who are taught as students. Likewise the learning of al-Qur'an reading requires educators and students. The Prophet Muhammad as the first person to receive the revelation of the Koran has provided an example of the learning process of reciting the Koran. History has noted that God as the owner of the Qur'an delegates the angel Gabriel to become a "teacher" who corrects the Qur'anic recitation of the Prophet Muhammad. This is recorded in a narration of Imam Bukhari;

"Ibn Abbas said about the word of God," Do not move your tongue in reading the Qur'an in a hurry "Ibn Abbas said, that the Messenger of Allāh tried to overcome difficulties when receiving revelation, by moving his lips. Ibn Abbas said, "I moved my two lips before you as the Prophet moved his lips." Sa'id said, "I moved it like Ibn Abbas moved," then the verse of 
the Qur'an comes down, "Do not move your tongue in reading al-Qur'an in a hurry, in fact We have collected it (the Qur'an) "He said," Allah has gathered the Qur'an in your heart and read it. "Allah said," If We recite the Qur'an 'follow the reading. "Or" listen and be quiet, "God said," Then We are the only to give the explanation, "then you read it to us (the Qur'an). Rasulullah SAW, when Gabriel visited him, listened carefully; then when Gabriel left, he read it as Gabriel read. "'

The position of the angel Gabriel as a listener and the Prophet Muhammad as a person who was listened to in the history led to a learning theory of al-Qur'an reading which requires a meeting between the instructor and the learner. This learning method continues from generation to generation, namely someone who learns to read the Qur'an must have a teacher. The Companions studied with the Prophet Muhammad, the Tabi'in studied with the Companions and followers of the tabi'inwith the tabi'in. So on, the Kiai (teachers) taught their students, to become Kiai, and then taught their students, so that there were scientific networks between teachers and students. ${ }^{\dagger}$

This tradition has also been entrenched in Indonesian society. However, along with the advancement of science and technology, the method of learning to read the Koran is also increasingly sophisticated. Through the internet network that can be accessed in computers or even cellphones, one can easily find material or theories of learning to read the Koran. One example of the Qur'an learning program through technology includes:

1. Quantum Reading Qur'an by Ust. Abu Rabbani.

Easylearning to read the Qur'an method "AYU AYUN MANNATHAHAN" (focus on Mad Thabi'i and Ghunnah learning) watched 707,002 times, uploaded on June 14, $2016 .^{3}$

2. Learn to Read the Qur'an with the correct Tajweed by Ust. Ahmad FaridHasan. This learning only exemplifies reading al-Syamsiyah surah. Watched 2,267,469 times, uploaded on December 7, 2016. ${ }^{4}$

3. Learning Techniques and Tricks to Read Al-Qur'an correctly The "Al-Nur" method by Ust. H. Muammar Z. A. This method uses Arabic numerals. Watched 16,856 times, uploaded on February 2, 2018. ${ }^{5}$

4. An easy way to recite al-Qur'an by Ust. Yudi Imana.

An easymethod of reading the Qur'an which is introduced in the form of software. This application has been watched more than one thousand fifteen hundred times. ${ }^{6}$

Some programs on YouTube about learning to read the Qur'an provide theories of recitation of makhārij al-ḥurūf, the law of reading nūn sukūn and tanwīn, the letters $r \bar{a}^{\prime}$, and so on. Programs like this can be used by anyone who wants, both academic and non-academic, both young and old. Thanks to this technological advancement, someone who wants to learn to read the Qur'an is simply to sit in front of a computer or hold a cellphone, without having to go to a particular place with a particular teacher.

This is a phenomenon that nowadays occurs in this country. Learning al-Qur'an like this is so comfortable that it is not realized that it has eliminated the two main conditions exemplified by the Prophet Muhammad, namely Talaqqī and Musyāfahah. Talaqqī (meeting) means that the Al-Qur'an learning process requires meetings between teachers and students.

"Muhammad bin Ismā'il al-Bukhārī, Sah̄̄h al-Bukhārī (Egypt: Dār al-'Amiyah, 2013), 22.

†Aḥmad bin 'Alī bin Hajar Abū al-Faụl al-'Asqalānī al-Syāfî̀'̄, Fatḥ al-Bārī Syarh Ṣaḥ̄ḥ al-Bukhārī (Beirut: Dār alMu'arrafah, 1379), vol. 1, 681-682. 
However, only a meetingis not enough, so it must be equipped with Musyäfahah. That is, a teacher must be able to see clearly the mouth or oral of the student so that the teacher can correct each mistake directly. ${ }^{7}$

This is the problem which will be examined. The religious spirit of the Indonesian people that seems to be increasing should be directed properly. This study will explore several learning programs for reading the Koran on YouTube, especially those visited a lot. Do these programs allude to the importance of Talaqqi-Musyäfahah? Is there an offer to learn to read al-Qur'an based on technology but still pay attention to the Talaqqī-Musyāfahah?

\section{Methodology}

This type of research is library research, because the object of this research is a video that spreads among the community through social networking namely YouTube. The research steps that will be carried out are:

First, browsing some videos spread on YouTube social networks related to the learning process of al-Qur'an reading. There will be more searches on information circulating on the internet network related to YouTube videos.

Second, analysis on the search results using descriptive qualitative methods or approaches with semiotic analysis. The paradigm used is being critical with data collection techniques from YouTube videos.

Aims

This study aims first to categorize the learning program for reading al-Qur'an on YouTube, in terms of material. Second, to provide technology-based solutions but still withTalaqqī-Musyāfahah.

\subsection{Talaqqī-Musyāfahah in The Era of Prophet Muhammad}

The ability of the Prophet Muhammad to read the Qur'andid notcome suddenly, but through processes or stages. This process has been recorded in QS. al-Qiyamah verses 16-19;

"Do not you (Muhammad) move your tongue (to read the Qur'an) because you want to quickly (master) it. Verily We will gather it (in your heart) and read it. If we have finished reading it then follow the reading. Then verily We will explain it."

This group of verses explains the process of accepting the Qur'anic verses from Allah through the angel Gabriel to the Prophet Muhammad. There are six (6) educational values contained in those verses; first, there are teachers and students. This is reflected in God's communication (through Gabriel) as a teacher to the Prophet Muhammad as a disciple. The occassion of this verse is that when the angel Gabriel delivered several verses of the Qur'an to the Prophet Muhammad, spontaneously the Prophet Muhammad moved his tongue to mimic the verses of the Koran recited because he was afraid of forgetting. So, Allah reprimanded the Prophet Muhammad not to spontaneously imitate Gabriel's words. This is the main function of the teacher's presence in the learning process, including learning to read the Qur'an. a teacher can directly reprimand his student if there is a mistake. This is what talaqqi means, literally translated with meeting. Therefore, learning to read the Koran without the presence of a teacher in front of him is not the process of learning the Koran recommended by the Prophet Muhammad. ${ }^{8}$ 
Second, the teacher can clearly see the oral of the student. There is no slightest barriers that cover the face of the student and the face of the teacher, so the teacher can exemplify the way to read the verses of the Qur'an including how to pronounce the letters one by one in the verses.

Likewise students can easily see the oral of the teacher, then practice properly and correctly. Therefore, the process of reading the Qur'an in which there is something that hinders the oral of the teacher or student is not a learning process recommended by the Prophet Muhammad. This is what is called Musyāfahah, meaning that they each can see other'soral.

Third, there is patience, not being in a hurry. This attitude is also reflected in the verses. When the Prophet Muhammad recited the verse of Al-Qur'an by Gabriel, he hurriedly recited it by moving his mouth to imitate the teacher's words. With great compassion, God also rebuked the Prophet Muhammad, his disciple. Patience from the teacher or student is needed in the learning process, including learning to read the Qur'an. The tendency of the instantaneous modern society cannot be applied when they learn the Qur'an. Through this patience the teacher calmly delivers the material, as well as students can easily calm and comfortably receive little by little material from the teacher. Thus, the instant and hasty learning process of the Qur'an is not the learning modeled by the Prophet Muhammad. ${ }^{9}$

Fourth, the teacher has responsibility for the success of the learning process. This ethic is painted in the verses, when Allah affirms that it is His responsibility to collect all the verses of the Qur'an in the "chest" of the Prophet Muhammad. Prophet Muhammad did not need to fear that the verses were lost from memorization, thus disrupting the success of his preaching. Thus, the learning process of the Qur'an in which the teacher is indifferent, does not want to care for the success of his students, is not the sunnah or example of the Prophet Muhammad.

Fifth, listening then imitating. This ethic is found in QS. al-Qiyamah verse 18. God ordered the Prophet Muhammad to listen carefully to the verses of the Koran recited by the angel Gabriel, then imitated them. As with the acquisition of a baby's knowledge. The first source of knowledge is the sound that is heard, then imitated. This theory is ultimately used in the world of education. Allah's rebuke to the Prophet Muhammad, who rushed to imitate simultaneously, showed that students must listen first to the material being taught, then imitate it. This is the best method that has been exemplified by the Prophet Muhammad. ${ }^{10}$

Sixth, the teacher must provide an explanation. Verse 19 of al-Qiyāmah confirms that Allah as the owner of the verses of the Qur'an requires Himself to give to the Prophet Muhammad an explanation of revealed verses. This is part of the knowledge acquisition process that God has given. A student has the right to receive explanations of the material he receives. While the teacher has the obligation to explain the material. ${ }^{11}$

\subsection{Learning to Read al-Qur'an through Technology}

The learning process includes learning objectives, materials, methods and media, evaluation and feedback. A learning will succeed if you pay attention to this matter, including learning to read the Koran.

Technological progress greatly affects the spirit of someone to look for teachers to read al-Qur'an. At present, almost every human being has a cellphone (HP) as a means of communication and a means of providing all information, including knowledge of how to read the Koran. According to Christine Wibhowo and RidwanSanjaya, technology science is the result of human engineering to obtain or provide information quickly and more widely. The science of technology brings together high-speed communication and communication for data, voice and video. Technological advances bring positive and creative values for some people to 
continue to produce something. One of them is the application which makes it easy to learn Tajwīd. There are several choices of learning programs to read the Qur'an along with the knowledge of recitation which can be easily accessed from YouTube, including the method of 'Asyarah.

The method of 'asyarah is one method of learning to read the Qur'an. This method is presented in the form of software and was introduced on October 10, 2004 by YudiImana. The material presented is Makhārij al-Hurüf, Madd, Ghunnah, Qalqalah, Lām al-Ta'rīf, Madd Far' '̄, Lafdh al-Jalālah, Rā, and Idghàm laws. These materials are packaged in the form of song lyrics sung cheerfully so that they delight the users. This application has been watched more than $1,500 .^{12}$

Another method that is also widely visited is the Quantum Reading Qur'an Method which is guided by Abu Rabbani. One of the terms offered to facilitate material is "AyuAyunMannatahan". This term stands for "Ayu" and "Mannatahan". Ayu is an abbreviation of three mad letters namely a / I - y/ - u / و . If the reader of the Qur'an finds these three letters in a state of "sukūn" then the way of reading is swung so that the sound coming out will be in harmony with the two movements. While the term "Mannatahan" is manna is an abbreviation of the letter mim and nun with tasydid. If the reader of the Qur'an discovers the mim and nun letters with tasydid, the reading must be retained so that the sound coming out will be in harmony with two beats.

Abu Rabbani used the term to explain the reading of Madd Thabi' $\bar{\imath}$ and Ghunnah. According to him, it is often heard that someone who reads Madd Thabi' $\bar{\imath}$ exceeds the length should be two harakat. So, these two harakat he made easy with the term one swing. ${ }^{13}$

\section{Result and Discussion}

Two methods that have been described are a small part of the various methods of reading the Koran on YouTube. Search results for these videos show:

1. Generally, there are 2 video models downloaded; first, the video is the result of recording the learning activities of reading al-Qur'an as the method of 'Asyarah, so that there are communicative teachers and students. Thus, talaqqi-musyāfahah in the model can be found. Second, not the recording of learning activities but the recording of the teacher who explained the material of recitation. While the audience or students are the audience or anyone who is accessing it, as well as quantum reading quran. Thus, this model does not have talaqqī-musyāfahah.

2. Videos that have been traced have no one to access that the videos being watched are only supporting media that cannot be used as the main teacher.

3. Some people who have watched these videos say they feel they have learned enough to read the Koran through the internet.

4. When linked to the examples of the Prophet Muhammad that have been described in the previous chapter, it shows that:

Table 1. Result of Prophet's Way and Internet (Youtube)

\begin{tabular}{lll}
\hline No & Prophet's way & Internet (YouTube) \\
\hline 1 & Teacher: Allah through & Teacher: video \\
\hline
\end{tabular}




\begin{tabular}{|c|c|c|}
\hline & $\begin{array}{l}\text { Gabriel } \\
\text { Disciple: Prophet } \\
\text { Muh\}ammad }\end{array}$ & Disciple: viewer \\
\hline 2 & $\begin{array}{l}\text { Teacher can correct the } \\
\text { disciple }\end{array}$ & $\begin{array}{l}\text { Video has no } \\
\text { ability to correct }\end{array}$ \\
\hline 3 & Being patient, not in hurry & $\begin{array}{l}\text { Not in a hurry by } \\
\text { repeating watching } \\
\text { (playing) }\end{array}$ \\
\hline 4 & $\begin{array}{l}\text { Responsibility for learning } \\
\text { success }\end{array}$ & No responsibility \\
\hline 5 & $\begin{array}{l}\text { Students can listen and } \\
\text { imitate }\end{array}$ & $\begin{array}{l}\text { Students can listen } \\
\text { and imitate }\end{array}$ \\
\hline 6 & $\begin{array}{l}\text { The teacher explains } \\
\text { misunderstanding }\end{array}$ & It can not explain \\
\hline
\end{tabular}

Paying attention to the evaluation results, here we find many things required:

1. Socialization of the necessity of talaqqī-musyāfahah in learning to read the Qur'an.

2. If you are forced to use the internet it should be an online video call or the like so that the 6 points that have been exemplified by the Prophet Muhammad can be realized or accomplished.

\section{References}

[1] al-'Asqalānī al-Syāfî̀'̄, Aḥmad bin 'Alī bin Hajar Abū al-Faḍl.Fatḥ al-Bārī SyarhṢaḥ̄ḥ alBukhārī, Beirut: Dār al-Mu’arrafah, 1379.

[2] al-Bukhārī, Muhammad bin Ismā’il. Ṣaḥihh al-Bukhārī,Mesir: Dār al-'Amiyah, 2013.

[3] Badr al-Dīn al-'Ain̄̄, Abū Muḥammad Mạ̣mūd bin Ạ̣mad bin Mūsā bin Aḥmad bin Ḥasin al-Ghitābī al-Ḥanafī. 'Umdah al-Qari' SyarhṢaḥ̄ḥ al-Bukhārī, Beirut: Dār Ihyyā' al-Turāth al-'Arābī, tt.

[4] Izzan, Ahmad dan Saehudin, Tafsir Pendidikan: Konsep Pendidikan Berbasis al-Qur'an, Bandung: Humaniora, 2015.

[5] Ibn Kathīr, Abū al-Fida' Ismā’il. Tafsīr al-Qur'ān al-'Az̄ìm, Beirut: Dār al-Kutūb al'Ilmiyyah, tt.

[6] Jihad, Asep dan Suyatno, Menjadi Guru Profesional: Strategi Meningkatkan Kualifikasi dan Kualitas Guru di Era Global, Jakarta: Erlangga, 2013.

[7] Muhammad, Ahsin Sakho dan Widati, Romlah.Manba' al-Barakāt F̄̄ Sab' al-Qirā 'àt, Jakarta: IIQ Press, 2015.

[8] Shihab, M. Quraish.Tafsir al-Mishbah, Jakarta: Lentera Hati, 2003.

[9] Sedek bin Ariffin, "Talaqqī dan Musyāfahah dalam Pembacaan Al-Qur'an", http://repository.um.edu.my/87964/1/Kepentingan\%20Talaqqī\%20Musyāfahah\%20Untuk\%20Jurnal $\% 20$ DQ.pdf

[10] Tim Laboratorium Pancasila, Bangsa Indonesia dalam Dinamika Reformasi, Harapan dan Tantangan, Malang: Laboratorium Pancasila Universitas Negeri Malang, 2001.

[11] al-Zuhaylī, Wahbah Mușțāā.Tafsīr al-Munīr, Beirut: Dār al-Fikr, tt.

[12] M. One, "Belajar Mengaji dari Dasar", https://www.YouTube.com/watch?v=3yF1S6gsDg0

[13] Bimbingan Tilawatil Qur'an dan Ceramah Islam, "Trik Belajar Cepat Membaca Al-Qur'an dengan Metode An-Nuur", https://www.YouTube.com/watch?v=BdvDY05MFB8

[14] Alfin Hanafi, "Quantum Reading Quran” https://www.YouTube.com/watch?v=G634zJOa08w 
[15] Cumangitu Channel Anak, "Belajar Membaca Al-Qur'an dengan Tajwid yang Benar", https://www. YouTube.com/watch?v=oZP3R1 vso4

[16] http://www.funtahsin.com/2011/05/metode-asyarah.html 